"This is the author-created version.

The final publication is available at www.springerlink.com

http://dx.doi.org/10.1007/s11195-013-9287-7"

\title{
"Hip to be Crip?" About Crip Theory, Sexuality and People with Intellectual Disabilities
}

\section{Lotta Löfgren-Mårtenson}

\begin{abstract}
This article examines the value of using Crip Theory by investigating what is considered normal sex life for people with intellectual disabilities in Sweden. By combining Crip Theory with Gagnon and Simon's sexual scripting theory, it concludes that Crip Theory can be of use for researchers and activists, and also suitable for educating staff members, in that it questions sexual norms that are most often taken for granted. However, due to the fact that research or activism inspired by Crip Theory seldom includes intellectual disabilities, its usefulness is limited, and more work is needed to solve problems surrounding agency, stigma and visibility.
\end{abstract}

Keywords: Crip theory, Script theory, Intellectual disability, Normalization process, Sexuality, Sweden

\section{Introduction}

Recently, theoretical crip concepts and perspectives have been used by both activists and researchers studying disabilities, not only in the US and the United Kingdom, but also in Sweden [1-4]. The term "Crip" has parallels to queer, which is now so widely used and known in Sweden that some politicians even state that they are "queer"1. Both constructs revolve around the dialectic between the "normal" and "abnormal", albeit with a certain difference in focus. This dialectic also permeates the construction of sexuality and can be examined from a queer perspective; by adding crip theory, the focus illuminates the constructs and meaning of "functionally impaired" versus "able-bodied." According to crip theorist Robert McRuer [6], both terms are initially aggressive and have been used as terms of abuse and negative epithets. But by claiming the power of the terms themselves and appropriating them, the perspective is reversed and the stigma embraced [4, 7]. Since the crip perspective so far has been mainly used to examine issues of physical impairments, the following review examines its applicability to sexuality and intellectual disability ${ }^{2}$. The question is thus whether the use of a crip perspective is useful or problematic in this area.

Through the perspective that borders between queer and crip, the so-called "normalization process" that includes social policy reforms implemented in Sweden and other Scandinavian countries in the 1970 s is analyzed. Precisely what is the meaning of the normalization process for the sexuality of individuals with intellectual disabilities?

\footnotetext{
${ }^{\top}$ For example, Swedish politician and former Deputy Prime Minister Mona Sahlin has made a statement about "more queer politics" [5].

${ }^{2}$ The term intellectual disability is recommended since 2007 by the Swedish National Board of Health and Welfare [8] instead of "mental retardation." It also discourages the term "handicap", and defines the concept of disability based on the importance of obstacles in interaction with the environment.
} 
How do you define "normal" sexuality, and does it differ from the perception of sexuality in people with intellectual disabilities? The article also aims to forge a theoretical Crip perspective to the interactionist theory of sexual scripting [9], by highlighting the restrictive script directed towards persons with intellectual disabilities.

\section{The Emergence of Crip Theory}

Crip theory builds on queer theory's critical tradition of norms, partly through its strong link to the activist movements that emerged in response to experiences of societal and social injustice. The most significant similarity between Crip and queer is the radical critique of the concept of normativity [9]. But instead of questioning heterosexuality, crip theory turns our attention to how physical ableism is created and in turn questions its normativity [1, p. 5]. Just as queer theory problematizes heterosexuality rather than homosexuality, ablebodied functionality is examined by Crip. Why is a "perfect" and functioning body better and more desirable than another? What exactly is a normal body? Why do hearing impaired individuals need to obtain functional hearing through surgery assisted by the latest technology? Is it unquestionably better to leave a subculture composed of people with similar life issues and a common sign language and switch, in order to belong to "the hearing"?

Researcher Robert McRuer writes in his seminal work Crip theory: Cultural signs of queerness and disability [6] that, as with queer, the choice of the term crip is meant to be provocative. "Crip" is short for cripple, generally regarded as a strongly derogatory word. Instead of being addressed as someone different, such as "functionally impaired", "mongo" or "gimp", the choice is there to call oneself crip and experience pride. Historian Jens Rydström [3] points out that an impaired individual can use the word and openly show his or her stigma in lieu of hiding it or feeling shame. The individual is not seeking tolerance, but wants to embrace and actively appropriate the stigma. Similarly, the term "hip to be crip" in the title of this article is used to highlight the positive aspect of taking control of other people's perceptions and expressions about oneself.

Rydström [3, 4] points out that impairment may exist only as a contrast to ablebodiedness. But this is a non-identity, which constitutes the norm, and therefore cannot be identified as a specific position [1]. The "normal" can only exist if something else is "abnormal". McRuer [6] believes that crip is a consciously adopted position, a critical questioning of the norm and how our society privileges the idea of a body. It is then possible to criticize and question able bodiedness from the position of "critical disability", which Berg and Grönvik [1] define as a "deliberate disability". Unlike the identity of being disabled, which involves an involuntary alienation, there is a conscious identification with being excluded-a possible stance from which to critically examine the norm $[1,6]$. McRuer $[6, p .2]$ highlights a discussion of what he calls "compulsory able-bodiedness" that he believes in itself produces disability. In the realm of the unspoken concerning the body's abilities, a functional, able body is expected to be the norm [2]. Crip theory therefore criticizes the standards that maintain the boundaries of the "normate", another word that is often used in crip and represents the idea of the able-bodied individual $[6,11]$. To ensure the survival of the normate, society learns to tolerate the deviant up to a certain limit, whereas the identity of the normate remains flexible. The flexibility is necessary to maintain the dichotomy of normal/abnormal and ability/disability. 
McRuer [6] also states that it is not possible to speak of the disabled as a group, even if he does not distinguish between different types of disabilities or makes a distinction between the physical and the intellectual. The differences between someone who has a physical disability and an individual who has limitations in abstract thinking, in understanding processes and context, and in communication skills, are of course great. At the same time, crip theory is skeptical of institutionalized categories with clear boundaries between themselves [1]. Similarly, Lo" fgren-Ma ${ }^{\circ}$ rtenson [12, p. 220] notes that there is a diversity of expression within the group in a study of young people with intellectual disabilities who have considered their opportunities and obstacles to love and sexuality:

In the crossroads of the overall societal changes, different social conditions and individual variations that now exist, different actors with developmental disabilities are emerging all the more clearly, each one as an individual, and in their own way wanting to be involved in creating their own circumstances. At the end of this research journey, there is not, and never has been, any given group that can be called "the developmentally disabled."

\section{From Institution to Group Home: a Normalized Life?}

Historically, the sexuality of people with intellectual disabilities has been linked to problematic expressions (e.g., masturbating in public, pathological exhibitionism), while the standard "normate" sexuality belongs to the socially accepted (heterosexual intercourse leading to the creation of nuclear families). During the early 1900s in Sweden, the majority of adults with intellectual disabilities remained in large single-sex institutions for life, surrounded by high walls and usually located outside main metropolitan areas. These institutions were established as a result of both social care and norm control of so-called deviant persons [13-15]. Care was based on philanthropic ideas laid out in a rehabilitative perspective and strove to "cure" disabilities [16]. Through special training and a Christian upbringing, the problem of "the handicapped" would lessen, and therefore the burden of society to care for its dependents. Additionally, formal diagnoses and drug treatments became accepted means to address human problems and create a kind of scientific systematization of society's welfare system. But these institutions were also charged with the societal control of the sexuality of people who were regarded as misfits or otherwise deviant. It was deemed important to control reproduction, since social problems were believed to be inherited. Those with "inferior genes" should be prevented from procreating $[13,17]$. In order to be released from an institution, the patients would thus be required to undergo surgical sterilization. We can conclude that from a crip perspective, this was a markedly significant measure to distinguish the sexuality of the developmentally disabled from the "normates".

At the end of 1960s and the beginning of the 1970s, there was a radical change for people with disabilities in the context of social reforms concerning integration, participation and normalization [18]. It was now considered better for children to grow up with close family members rather than in an institution or a specialized school [19]. Large nursing homes and special hospitals were eventually phased out, and most of those who were born in Sweden in the 1970s and beyond have been reared in their family of origin while attending integrated childcare and special education schools [20]. When it is time for the adolescent to leave home, it is now to a residential group home accommodating 4-6 people. 
Research shows that efforts towards normalization and integration are not completely fulfilled in practice [20]. Critics argue that one of the difficulties in fulfilling legislative intentions deals with the large number of assistance personnel that surround people with disabilities in everyday life [16]. In practice, caregiving staff has a determining role in the life of the impaired individual, rather than the individual acting on his or her own behalf as Swedish governing law has stipulated. Peterson [16, p. 221] believes that this "invisible, subtle network of health care professionals [...] perpetuates the old patriarchal, repressive and philanthropic traditional view of humanity." Based on crip theory perspective and concepts of visibility, agency and stigma management, this is observation worthy of some concern.

In contrast, other integration research indicates positive results, prompting Gustavsson and Söder [21] to state that the effects of social integration are inconclusive since unambiguous results are lacking. The integration policy has had different meanings, has been implemented in different ways and with varying degrees of enthusiasm in various places. Moreover, it has been implemented with varying degrees of expertise in various environments. Nowadays, the term "inclusion" is increasingly used, mainly to note that society should encourage a sense of belonging for all its members. The intent is that people with disabilities should not need any particular integration into society, because they are already full-fledged members thereof. Consequently, it would mean that the intentional visibility pointed out by crip theory should also include people with intellectual disabilities. But is that the case?

\section{New Challenges or New Walls?}

Normalization ideology has also meant that people with intellectual disabilities should be entitled to satisfactory sexual experiences like all others (e.g., [22]). This leads to an assessment of contemporary sexuality among people with intellectual disabilities. Are they living like "everyone else" in terms of private and family life, including the possibility of sexual expression in this context? If "normal life" means living in heterosexual relationships and/or in nuclear families, then there is evidence that social relationship patterns differ considerably for people with intellectual disabilities, both internationally and in Sweden [12, 23]. Most Swedish adults with intellectual disabilities are still living in group settings that they have not chosen for themselves, instead of being coupled or living in nuclear families [20].

In the wake of the normalization process, new challenges arise in the understanding and acceptance of the sexuality of people with intellectual disabilities. Special needs educator Barbara Ludlow [24] points out that neither the empirical research on various sexual expressions, experiences and actions, nor the development of appropriate models of provision of sex and relationship knowledge has kept pace with new approaches and resolutions to the problem. Instead, research shows ambivalence toward sexuality of people with intellectual disabilities, where concern and sense of responsibility are paired with control and doubts about what is permitted $[12,25]$. One explanation is that caregiving staff largely remains without the guidance, supervision and training that provide the ability to critically examine what are considered "normal" and "abnormal" expressions of sexuality. And when the staff does not have experiences other than their own to use as comparisons and define these as normal, the risk is that a dominant and controlling approach arises [26, 27]. 
Much indicates that the normalization principle from a gender perspective is characterized by stereotyped gender thinking [28-31]. A contributing factor may be the wish that people with disabilities in no way deviate from the norm. If the prevailing norm contains a traditional view of masculinity and femininity, the consequence may be that it will be even harder for someone with intellectual disabilities to deviate from it. The years of institutionalization, their strict gender segregation and repressive views on relationships and parenthood still affect today's men and women with intellectual disabilities, according to many critics [28]. Because of a long-standing tradition of hostility in the institutional environment, some women with intellectual disabilities may reflect negatively on their ability to become parents [32,33]. Although it is difficult to speak unequivocally about Swedish social perceptions of parenting and intellectual disabilities, the situation is probably more positive today than a few decades ago [34]. However, we still know very little about the extent to which people with intellectual disabilities have children, and the sociodevelopmental trajectory of these families. This is partly because it is sometimes difficult to define this particular group, since those who become parents often have a mild intellectual disability that is not always clearly diagnosed $[35,36]$.

The normalization process thus appears to have affected the sexual environment of people with intellectual disabilities only on the surface [12, p. 214]. In practice, there are only references to what personnel and relatives consider normal and acceptable sexual behavior. As a consequence of the daily need for assistance, there are no opportunities for a private sphere where sexuality can be expressed in a socially accepted way to the same extent as for the non-disabled. This can be connected to the theory of sexual scripts, which can also be used to analyze a "system of normative sexuality".

\section{The Restrictive Script}

According to Gagnon and Simon [9], sexuality is located within a sociological and social constructionist framework. They argue that sexuality is a learned behavior and therefore can, and should, be studied like any other learned behaviors. They emphasize that behavior can be explained by a continuous process and in interaction with the environment in which the developing individual incorporates the values and norms of the dominant society. Gagnon and Simon [ibid.] developed the theory of sexual scripts, i.e., basic tenets stating that we learn a script to express sexuality that depends on issues of when, where, how, with whom and why [37]. The particular script concerning our relation to sexuality includes temporal, cultural and societal norms, as well as values influenced by normativity. Sexual activities are therefore never conducted in a vacuum but in a cultural context, which also means that scripts are never static but constantly changing and differing, depending on toward whom they are directed. For example, sexual scripts directed toward people with intellectual disabilities appear to be more restrictive than those directed toward "normates" [38]. One explanation for this restrictive script could be that in caregiving settings, the staff's sense of responsibility leads to controlling behavior, in order to prevent anything "bad" from occurring. A female staff member talks about the dilemmas employees may face in these settings [12, p. 121]:

There is sex involved. If they fall in love and DON'T have sex, it's really nice for sure. But if they are they going to fuss and make a mess and that kind of stuff: "uh, uh, uh"... Then it's probably not as cozy anymore. There is a clear boundary between... falling in love without sexuality, being in love that includes sexuality, or sexuality itself... well, that's not what we're talking about (laughs)! 
Because of concerns about the "darker" side of sexuality, adolescents and young adults with intellectual disabilities are protected from sex and are rarely given opportunities to meet on their own, without staff or other adults. Another example of the restrictive sexual script is the lack of sex education in schools. A pilot study in which special education students were interviewed reveals that many are unsure whether they have had any sex education at all, and many are wondering what the subject actually means [39]. Those students who have had some sex education state that there is a focus on how to protect oneself from unwanted pregnancies, sexually transmitted diseases and sexual risk situations. At the same time, the interviews show that many people have a vague idea of how reproduction works. An 18-year-old girl who attends a business vocational training class describes the process $[39$, p. 9]:

The woman and the man. He has a weenie. And then he is close to the mommy's stomach. And then the egg is cracked in the mommy's tummy and comes out! In various ways, from here (points between her legs) or from here on the stomach.

A Norwegian study has shown that schools generally act as a "hetero factory", where standards for what is called a "good life" are created by policy documents, teaching materials, and social activities [40]. In the case of special education schools, it appears that staff often think that intellectual disability in itself is sufficiently "different", compared to being non-disabled [41]. If sexuality also deviates from the norm, it becomes an issue of too much deviance. The consequence is that young people with intellectual disabilities who are also gay, lesbian or gender-variant are at risk for becoming invisible. It is difficult for them to find unique role models or live differently from the norm [41, 42]. A 19-year-old youth who attends a vocational training class, where there has been a discussion of the subject, appears relieved [39, p. 11]:

Umm...we talked about some of that stuff too [...] It was good because I myself have... been with a guy before.

One explanation for the heteronormative approach is that school teachers are rarely given training on the subject of sex and relationships, thereby making their own uncritical frames of reference a basis for the teaching content and design [43]. And, since contemporary discourse is not about prohibition but about responsibility for the well-being of the adolescents, young people with intellectual disabilities are often subject to what staff and relatives consider normal and acceptable sexual behavior [39]. In general, the prevailing norms revolve around what others believe is normal behavior for people with intellectual disabilities. Hence, how can these norms be analyzed by using the perspective that is at the intersection between queer and crip?

\section{Sexless and Desexualized?}

People with intellectual disabilities seem to be crip regarding their intellectual ability while their sexualities are queer, i.e., they violate the norm of what is considered "normal" sexuality. Aside from the fact that most do not live in heterosexual dyads, have children and/or nuclear families, previous research also shows that their sexuality rarely includes intercourse [12]. Instead, there are a variety of sexual expressions, variations and directions, experienced by individuals living mostly as singles [ibid]. 
Yet, there is a desexualization of people with intellectual disabilities. Through the restrictive sexual script that is directed towards people with intellectual disabilities, it is more or less decided that sexuality should not lead to children; it should not involve "one night-stands"; it does not include homosexual or bisexual relationships; and, it is not to include relationships with a large age difference, or be too explicit or even overt in any way. These prohibited sexual expressions, behaviors and potential erotic targets all violate norms that specify others' opinions of how people with intellectual disabilities should express their sexuality. Indeed, compilation studies on youth and sexuality show data in which so-called "good sex" is generally advocated [44], something which has been criticized by, among others, queer researcher Don Kulick [45]. But this is even more pronounced in the case of young people with intellectual disabilities, where sexual variations and expressions that fall outside the norm are perceived as a problem among staff in group homes, habilitation centers and special education facilities [12, 23, 38, 46, 47]. In addition, research has shown that any potential partner for an adolescent with intellectual disabilities is examined from the viewpoint of being a "good boyfriend or girlfriend" to the other [12]. What is meant by this and who determines it is unclear.

The dependence on others because of their disability means that it is not possible to protest, rebel or do things in secret like other adolescents. It is also more difficult in general to attain a measure of adulthood, regardless of age (see [23]). A young man, Kristian, says that his parents have specifically indicated appropriate girls for him to associate with. Furthermore, he must ask the girl's parents if they can be together. Kristian explains [12, $p$. 113]:

Well, one can always ask them... her parents... if she is allowed. My girlfriend lived at home, and then you had to ask the parents... And know how old she is... but I don't know that... But... she must be... nineteen. It doesn't matter if it's a little different.

The intellectual disability also leads to varying degrees of limited ability in terms of timing it is difficult to know when it is socially acceptable to flirt, take any kind of sexual initiative and even to express sexual feelings and needs. Moreover, young people with intellectual disabilities are also grappling with the ability to express their attraction towards the "right" potential partner.

On the whole, it becomes clear that relatives and staff at all times see the sexuality of people with intellectual disabilities as different from their own, and that two specific categorizations have emerged: one pertaining to "disabled people's sexuality" and another for "other people's sexuality" [26, 48]. "Disabled people's sexuality" is seen as unnatural and public, while their own is seen as natural and private [48]. As a result, individuals with disabilities are often exposed to an unsolicited transparency of the private versus the public more or less around the clock, while behaviors and expressions are gauged on the basis of staff perceptions and images of so-called "normal sexuality". Deviations from the norm are interpreted as perversions, immature emotions, etc. As sexual expressions become endowed with causality, the "abnormal" is also accepted with regard to the intellectual disability [26]. The idea of a specific type of sexuality is thus established solely for people with intellectual disabilities. 
Further categorization can be linked to gender, where views of young men and women with intellectual disabilities differ. The men are seen more as "oversexed" and women as more "asexual", or at least uninterested in sexuality. Women are also seen as potential victims in situations fraught with sexual risks [25, 33]. Pornography consumption, exhibitionistic masturbating and instances of sexual harassment and abuse emerge in descriptions of men with intellectual disabilities, while women are rarely placed in this category (see $[25,48]$ ). International studies of women with intellectual disabilities indicate that they are not at all socialized to take the sexual initiative, whether heterosexual or homosexual [33]. Furthermore, stereotypical gender roles in relationships are also described in both international and Swedish research, where men with intellectual disabilities take the initiative and are more proactive than women [32, 33, 49]. However, recent Swedish studies have revealed a somewhat transposed gender role pattern in which young men with intellectual disabilities are uncertain when and if their sexuality is permitted at all [12]. They have repeatedly been told that they should be "cautious" against women and that it is important to never do something sexual against someone's will. The consequence is that young women with intellectual disabilities now direct and initiate the sexual encounters.

\section{The Utility of Crip Theory: a Discussion}

In returning to the initial question about the utility of crip theory when examining the perception of sexuality in people with intellectual disabilities, we can first conclude that McRuer [6] does not make any reference to intellectual disabilities in his writing. Instead, the theory proceeds from people with physical disabilities, i.e., individuals who have a voice, who can write about their situation, and organize dissent, and who is often found in the international disability rights movement (see [50]). But should not the movement also aim to include people with intellectual disabilities to ameliorate their quality of life? Even Sandahl [10] argues that the concept of crip should be able to expand, just as queer has done to include more groups, given its fluid and mutable nature. Indeed, she states that she never heard a non-disabled individual self-label as "crip" (compared to heterosexuals who now can call themselves queer), but that it should at least be possible [ibid.]. The question is whether all people with intellectual disabilities have the same opportunity to understand what it means to "embrace the stigma" and to charge the word "crip" with positive aspects. Perhaps the responsibility relies on others, among them normates, to offer and open up these opportunities?

Moreover, crip can be used to explore the possibility of private spheres where people with intellectual disabilities can express their sexuality in ways that are considered socially acceptable. By using the crip perspective, it becomes possible to problematize why and how the sexuality of normates, which usually happens out of plain sight, is regarded as normative and fully accepted. This review has also shown the applicability of sexual scripting theory to connect with crip and further strengthen a norm-critical perspective. The sexual script that is directed toward people with intellectual disabilities regarding the when, where, how, with whom and why, is clearly more restrictive than the one directed toward the normate. There is also a greater flexibility for normates to relate to their own sexual scripting, while individuals with intellectual disabilities encounter more difficulties to express sexuality in secret, or being able to protest the controls and restrictions imposed by others. 
The questioning of categories in Crip theory means that there is no conceptual difference between people with different types of disabilities. Fundamentally, the issue revolves around people having a wide variety of needs throughout the life span, from infants 'needs for care, to parents' needs for childcare, to elderly individuals requiring caregiving, without being labeled as "disabled" and considered worthy of pity or contempt. This inquiry points to a choice of perspective and willingness, to pioneer new ways to examine the issue and to challenge the seemingly self-evident and obvious. The theory of crip, its perspectives and its concepts can be used to examine the living conditions of people with intellectual disabilities, as issues of visibility, agency and stigma are brought to the forefront. One example is how the integration of disability in society has led to a power shift, from an institutional staff hierarchy to multiple assistants and other care staff, rather than being transmitted directly to the individual. Proceeding from crip theory, it now becomes possible to problematize concepts such as "normal" and "normalization". In what way and by what measures should the intellectually disabled individual become "normalized?" What sort of yardstick is used to achieve this goal? Who determines the nature of the perspective and the validity of individual needs and desires? These issues and how a "normal" life should be lived tend to be determined by the interpretations of others, and not by those whose lives and experiences are in question. Therefore, crip theory can also be useful in training staff that come into contact with other people's privacy in ways they rarely would otherwise.

Since crip theory possesses an inherent strength that can build bridges between activism and academia [1, p. 4], it behooves future disability researchers to include persons with intellectual disabilities in both research designs and the choice of methods. If the ideological starting point of the researcher and even the normate is rooted in the dominant discourse, there is a risk of nuanced and multifaceted knowledge rendered invisible, and for the the sexuality of the disabled to be defined as abnormal. It then becomes important to critically examine disability research revolving around living conditions that have shown fundamental differences between people with and without disabilities (see $[19,20])$. Many studies have idealized the normate's life, which brings us to the questionable aim of normalizing people with intellectual disabilities; in what way should this normalization process occur, and what is the end point? Is it a given that there is the want, the need, and the opportunity to achieve the ideal of heterosexual couple, having children and forming a nuclear family? Using crip theory can thus be helpful in analyzing perceptions of an ideal life, while uncovering and questioning the assumptions that often characterize disability research.

Nevertheless, the examination of the sexuality of people with intellectual disabilities in this borderland between queer and crip can also have its limitations, as the starting point of the analysis risks being unclear and confusing. For whose sake is there yet another theoretical perspective introduced into the sexuality of people with intellectual disabilities? Is it for the benefit of the researcher who does not want to belong to the traditional disability research field, but rather to a "hip-crip social movement"? In addition, this review has revealed that crip theory is not sufficient to analyze the research field itself, merely by combining it with sexual scripting theory. Intellectual disabilities are rarely included in crip inspired research and more work is needed to solve the problems that arise around actors, agency, stigma and visibility. 
Despite this limitation, focusing on the construct of "normal"/non-disabled versus "abnormal"/disability should create new knowledge and make visible the hidden discourse underpinning the traditional treatment and the prevailing view of sexuality of people with intellectual disabilities. An Australian study describes how to address these issues by challenging the dominant construction of sexuality as a biological function, which is propagated to intellectually disabled individuals as dangerous and consisting mainly of penetration [51]. Instead, a voice is given to a less dominant discourse that is focused on enjoyment, pleasure and intimacy from the individual's own perspective. New meanings and implications can be given to the concept of intellectual disability by studying the discourse of the non-intellectually disabled. Categorizations such as hetero/homo, normal/ abnormal and functionally impaired/able-bodied are made visible and thereby discussed and reviewed. And surely, that could not be wrong-only hip.

\section{References}

1. Berg, S., Grönvik, L.: Crip-Theory-en preliminary positionering. (Crip theory - apreliminary positioning). Centre for Gender Studies, Stockholm University, Stockholm. http://www.kvinfo.su.se/seminarieserier/CripTheory-enintroduktion.pdf (2007). Accessed 12 February 2012

2. Ericson, L.: Från könlös och avsexualiserad till sexuell och kåt: en intersektionell studie om sexualitet och funktionshinderskap utifrån ett cripteoretiskt perspektiv. (From sexless and asexual to sexual and horny: An intersectional study of sexuality and disability from a crip theory perspective). Master's Thesis. Centre for Gender Studies, Stockholm University, Stockholm (2010)

3. Rydström, J.: Cripteori om sex och funktionsnedsättning. (Crip theory about sex and disability). Framtider: Tema sexualitet. 4, pp. 21-24 (2009)

4. Rydström, J.: Crip-att omfamna sitt stigma. (Crip-to embrace its stigma). Research on Disability Continues 1: pp. 6-7 (2010)

5. Kulick, D.: Introduktion. (Introduction) In: Kulick, D (ed.), Queersverige. (Queer Sweden). Natur och kultur, Stockholm (2005a)

6. McRuer, R.: Crip Theory: Cultural Signs of Queerness and Disability. New York University Press, New York and London (2006)

7. Goffman, E.: Stigma: Notes on the Management of Spoiled Identity. Prentice-Hall, Englewood Cliffs (1963)

8. Swedish National Board of Health and Welfare: Frågor och svar: Funktionsnedsättning och funktionshinder. (Questions and Answers. Impairment and disability). Stockholm. http://www.socialstyrelsen.se/fragorochsvar/funktionsnedsattningochfunktion (2007). Accessed 1 September 2011

9. Gagnon, J.H., Simon, W.: Sexual Conduct: The Social Sources of Human Sexuality, 2nd ed. Aldine Transaction, New Brunswick and London (2005)

10. Sandahl, C.: Queering the crip or cripping the queer? Intersections of queer and crip identities in solo autobiographical performance. GLQ. 1, pp. 225-256 (2003) 
11. Thompson, D.: The sexual experiences of men with learning disabilities having sex with men. Issues HIV prev. Sex. Disabil. 3, pp. 221-242 (1994)

12. Löfgren-Mårtenson, L.: Får jag lov? Om sexualitet och kärlek i den nya generationen unga med utvecklingsstörning. (May I? About sexuality and love in a new generation of young people with developmental disabilities). Studentlitteratur, Lund (2005a)

13. Engvall, K.: Asociala och imbecilla: kvinnorna på Västra Mark 1931-1967. (Anti-socials and imbeciles): Women at Västra Mark [1931-1967]. Örebro University, Örebro (2000)

14. Foucault, M.: Sexualitetens historia. Vol. 1. Viljan att veta. (The history of sexuality: Vol. 1: The will of knowledge). Bokförlaget Daidalos, Göteborg (1976/2002)

15. Färm, K.: "Socialt problem" eller "som andra och i gemenskap med andra": föreställningar om människor med utvecklingsstörning. ("A social problem" or "Like others and in common with others" - beliefs about people with developmental disabilities). Linköping University, Linköping (1999)

16. Peterson, G.: Specifik och generell lagstiftning. (Specific and general law). In: Tideman, M. (ed.) Perspektiv på funktionshinder \& handikapp (Perspectives on disability and handicap), pp. 208-224. Johansson and Skyttmo, Falun (1996)

17. Jönsson, L.-E.: Ett skarpt vapen - om sterilisering som alternative till anstaltsvistelse. (A sharp weapon-sterilization as an alternative to an institution stay). In: Broberg, G. (ed.) Fem uppsatser om sterilisering i Sverige (Five essays on sterilization in Sweden), pp. 9-21. Lund University, Lund (2000)

18. Gustavsson, A.: Integrering som motkultur. [Integration as a counterculture - experiences from the first generation of integration]. In: Rabe, R., Hill, A. (eds.) Boken om integrering: Idé, teori, praktik (A book about integration: Concept, theory, practice), pp. 116-147. Studentlitteratur, Trelleborg $(1996 / 2001)$

19. Tøssebro, J.: En bedre jverdag? Utviklingshemmedes levekår etter HVPU-reformen. (A better daily life? The living conditions of the developmentally disabled after the HVUP-reform). Oslo (1996)

20. Tideman, M.: Normalisering och kategorisering: om handikappideologi och välfärdspolitik i teori och praktik för personer med utvecklingsstörning. (Normalization and categorization. About the ideology of the handicapped and the politics of welfare in theory and practice for persons with developmental disabilities). Johansson och Skyttmo, Sollentuna (2000)

21. Gustavsson, A., Söder, M.: Social forskning om människor med psykisk utvecklingsstörning. (Social research of people with mental disabilities). R \& D Report 1990:1. Stockholm (1990)

22. Held, K.R.: Ethical aspects of sexuality of persons with mental retardation. Sex. Disabil. 4, pp. 237-243 (1992)

23. Brown, H.: An ordinary sex life? A review of the normalization principle as it Applies to the sexual options of people with Learning Disabilities. Disabil. Soc. 2, pp. 123-144 (1994)

24. Ludlow, B.: Contemporary issues in sexuality and mental retardation. Adv. Ment. Retard. Dev. Disabil. 4, pp. 1-26 (1991)

25. Löfgren-Mårtenson, L.: Kärlek.nu. Om Internet och unga med utvecklingsstörning. (Love.now: The Internet and young people with intellectual disabilities). Studentlitteratur, Lund (2005b) 
26. Mallander, O.: De hjälper oss tillrätta: normaliseringsarbete, självbestämmande och människor med psykisk utvecklingsstörning. (They help us get it together: Normalization work, empowerment, and people with mental disability"). Lund University, Lund (1999)

27. McConkey, R., Ryan, D.: Experiences of staff in dealing with client sexuality in services for teenagers and adults with intellectual disability. J. Intellect. Disabil. Res. 1, pp. 83-87 (2001)

28. Atkinson, D., Walmsley, J.: A woman's place: Issues of gender. In: Philpot, T., Ward, L. (eds.) Values and Visions: Changing Ideas in Services for People with Learning Difficulties, pp. 218-231. Butterworth Heinemann Itd, Oxford (1995)

29. Brown, H., Smith, H.: Assertion, not assimilation: A feminist perspective on the normalization principle. In: Brown, H., Smith, H. (eds.) Normalisation: A reader for the nineties, pp. 149-171. Routledge, London and New York (1992/1998)

30. Walmsley, J.: Women: first Lessons in participation. CSP. 2, pp. 86-99 (1993)

31. Williams, F.: Women with learning difficulties are women too. In: Langan, M., Day, L. (eds.) Women, Oppression and Social Work: Issues in Anti-Discrimination Practice, pp. 149-168. Routledge, London (1992)

32. Barron, K.: "Who am I? Women with learning difficulties (re)constructing their self-identity. SJDR. 1, pp. 58-79 (2002)

33. McCarthy, M.: Sexuality and women with learning disabilities. Jessica Kingsley Publisher Ltd, London and Philadelphia (1999)

34. Ahlm, J.: Förståndshandikappade föräldrar-barnet, föräldrarna och samhället. (Intellectual disabled parents - the child, the parents and the community). Lund University, Lund (2000)

35. Kollberg, E.: Omstridda mödrar: en studie av mödrar som förtecknats som förståndshandikappade. (Controversial mothers: A study of mothers listed as mentally handicapped). Nordiska hälsovårdshögskolan, Stockholm (1989)

36. Swedish National Board of Health and Welfare: Föräldrar med utvecklingsstörning och deras barn: vad finns det för kunskap? (Parents with mental retardation and their children: What do we know?). No. 2005-123-3 (2005)

37. Gagnon, J.H.: The explicit and implicit use of the scripting perspective in sex research. Annu. Rev. Sex. Res. 1, pp. 1-43 (1990)

38. Löfgren-Mårtenson, L.: The invisibility of young homosexual women and men with intellectual disabilities. Sex. Disabil. 1, pp. 21-26 (2009)

39. Löfgren-Mårtenson, L.: "I want to do it right!" A pilot study of Swedish sex education and young people with intellectual disability. Sex. Disabil. 30(2), pp. 209-225 (2012)

40. Røthing, A., Svendsen, S.: Homotolerance and heterosexuality as Norwegian values. J. LGBT. Youth. 2, pp. 147-166 (2010)

41. Löfgren-Mårtenson, L.: Hur gör man? Om sexualkunskap i särskolan. (How do you do it? On sex education in special education schools). Argument, Varberg (2009b)

42. Abbott, F., Howarth, J.: Secret loves, hidden lives? Exploring issues for people with learning difficulties who are gay, lesbian or bisexual. Bristol University Press, Bristol (2005) 
43. Hållö, J.: Sex- och samlevnadsundervisning i grundsärskolans åk 6-10 och gymnasiesärskolans nationella program. (Sex and relationship education in special education schools year 6-10 and the national programs of secondary special education). Teacher Education, Malmo" University, Malmo" (2010)

44. Forsberg, M.: Ungdomar och sexualitet-en forskningsöversikt 2005. (Young people and sexuality-a research overview 2005). Statens folkhälsoinstitut, Stockholm (2006)

45. Kulick, D.: 400,000 perversa svenskar. (400,000 perverted Swedes). In: Kulick, D. (ed.) Queer Sweden. Natur och kultur, Stockholm (2005)

46. Nordeman, M.: När känslorna tar over: sexualitet, utvecklingsstörning, autism. (When feeling takes over: Sexuality, mental disability, autism). Carlsson, Falun (2005)

47. Thompson, D.: The sexual experiences of men with learning disabilities having sex with men; issues of HIV prevention. Sex. Disabil. 3, pp. 221-242 (1994)

48. Sundet M.: Jag vet jag er annerledes-men ikke bestandigt: en antropologisk studie av hverdagslivet til fem personer med psykisk utviklingshemming. (I know I'm different-but not always: An anthropological study of the everyday lives of five people with mental disabilities). Uppsala University, Uppsala (1997)

49. Flynn, M.: Independent Living for People with Mental Handicap: A Place of My Own. Cassell Educational, London (1989)

50. Shakespeare, T.: Disabled sexuality: towards rights and recognition. Sex. Disabil. 3, pp. 159166 (2000)

51. Chivers, J., Mathieson, S.: Training in sexuality and relationships: an Australian model. Sex. Disabil. 1, pp. 73-80 (2000)

52. Löfgren-Mårtenson, L.: “Hip to be crip?” Om intellektuell funktionsnedsättning, sexualitet och cripteori. Lambda Nordica. Tema: Cripteori 1-2(17), pp. 53-76 (2012) 